\title{
PUBLIC EDUCATION, NEOLIBERALISM, AND TEACHERS
}

New York, Mexico City, Toronto 
This page intentionally left blank 
PAUL BOCKING

\section{Public Education, \\ Neoliberalism, and Teachers}

New York, Mexico City, Toronto 
(C) University of Toronto Press 2020

Toronto Buffalo London

utorontopress.com

Printed in the U.S.A.

ISBN 978-1-4875-0660-5 (cloth) ＩSBN 978-1-4875-3251-6 (ePUB)

ISBN 978-1-4875-3450-9 (PDF)

\section{Library and Archives Canada Cataloguing in Publication}

Title: Public education, neoliberalism, and teachers : New York, Mexico City, Toronto / Paul Bocking.

Names: Bocking, Paul, 1984- author.

Description: Includes bibliographical references and index.

Identifiers: Canadiana (print) 20200176234 | Canadiana (ebook) 20200176269 |

ISBN 9781487506605 (cloth) | ISBN 9781487534516 (PDF) | ISBN

9781487532512 (ePUB)

Subjects: LCSH: Public schools - New York (State) - New York. I LCSH:

Public schools - Mexico - Mexico City. I LCSH: Public schools - Ontario -

Toronto. I LCSH: Education and state - New York (State) - New York. I

LCSH: Education and state - Mexico - Mexico City. I LCSH: Education and state - Ontario - Toronto. I LCSH: Teaching - New York (State) - New York. I LCSH: Teaching - Mexico - Mexico City. I LCSH: Teaching - Ontario -

Toronto. | LCSH: Neoliberalism.

Classification: LCC LC59 .B63 2020 | DDC 371.01 - dc23

This book has been published with the help of a grant from the Federation for the Humanities and Social Sciences, through the Awards to Scholarly Publications Program, using funds provided by the Social Sciences and Humanities Research Council of Canada.

University of Toronto Press acknowledges the financial assistance to its publishing program of the Canada Council for the Arts and the Ontario Arts Council, an agency of the Government of Ontario.

Canada Council for the Arts
Conseil des Arts du Canada

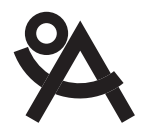

ONTARIO ARTS COUNCIL CONSEIL DES ARTS DE L'ONTARIO

an Ontario government agency

un organisme du gouvernement de l'Ontario 
For all teachers who cultivate wisdom and struggle for social justice 
This page intentionally left blank 